\title{
Translation and cross-cultural adaptation of the Nordic Occupational Skin Questionnaire (NOSQ-2002) to German
}

\author{
Maria Girbig ${ }^{1 *}$, Lene Seidler ${ }^{1}$, Janice Hegewald ${ }^{1}$, Christian Apfelbacher ${ }^{2}$, Andreas Seidler ${ }^{1}$, Stefanie Deckert ${ }^{1}$, \\ Karsten Rossa ${ }^{1}$, Jake Butler ${ }^{1}$, Mari-Ann Flyvholm ${ }^{3}$ and Jochen Schmitt ${ }^{1}$
}

\begin{abstract}
Background: Occupational skin diseases are among the most prevalent work-related diseases. The Nordic Occupational Skin Questionnaire (NOSQ-2002) is a useful standardized epidemiological tool which enables screening of occupational skin diseases. The objective of this study was the translation and cross-cultural adaption of the NOSQ-2002 into German with particular attention to the clarity, comprehensibility and appropriateness of the translated version.

Methods: The adaptation of the German NOSQ-2002 follows the Principles of Good Practices of the International Society for Pharmacoeconomics and Outcomes Research (ISPOR).

Results: After translation, the German version was tested by means of cognitive debriefing interviews. Overall, the translated German NOSQ-2002 was well understood by all 18 participants of the qualitative assessment. Only some modifications were required.

The whole process of translation and modification resulted in some minor alterations of the German NOSQ-2002 compared to the initial version. The result of the translation process is available at the Danish National Research Centre for the Working Environment (www.nrcwe.dk/NOSQ).

Conclusion: A linguistically validated version of the NOSQ-2002 is now available for German speaking regions. This is a prerequisite for future assessments of occupational skin diseases in accordance with international standards. Further research is necessary to examine the psychometric properties of the German NOSQ-2002.
\end{abstract}

Keywords: NOSQ-2002, Cross-cultural adaption, Occupational skin diseases, Hand eczema, Dermatitis, Urticarial, ISPOR

\section{Background}

In many industrialised countries occupational skin diseases are among the most prevalent work-related diseases [1-5]. For instance, in Germany, "severe or recurrent skin diseases which have forced the person to discontinue all activities that caused or could cause the development, worsening or recurrence of the disease" (occupational disease No. 5101) represents the most commonly reported suspected occupational disease [1]. Comprising 596 $(35.3 \%)$ of all recognized occupational diseases $(\mathrm{n}=1.687)$, it is also the most frequent one leading to a discontinuation of all damaging activities [6]. However, there is a

\footnotetext{
* Correspondence: maria.girbig@tu-dresden.de

'TU Dresden, Faculty of Medicine, Institute and Policlinic of Occupational and Social Medicine, Dresden, Germany

Full list of author information is available at the end of the article
}

huge discrepancy between reported and recognized cases, with only $596(2.4 \%)$ of the 24.805 suspected cases reported in 2012 being recognized as occupational skin diseases [6]. There are two reasons for this discrepancy. Firstly, some reported cases are not pursuant to German insurance laws. Secondly, the success rate of secondary prevention measures (e.g. optimized dermatologist procedure) is very high [7].

In order to enact prevention measures efficiently, an early screening which enables timely intervention is essential [8]. Early screening also ensures diagnosis of diseases in early stages where treatment is likely to be more beneficial. In addition, it helps to identify workrelated and non-work-related exposures that increase the risk of disease (e.g. allergens, working with gloves). 
However, currently no standardized instruments are available in German to allow such a screening. The Nordic Occupational Skin Questionnaire (NOSQ-2002), created by the Nordic Occupational Skin Questionnaire Group in 2002 is a recognized international standardized instrument for the assessment of occupational and nonoccupational risk factors for skin diseases, as well as the prevalence and course of skin diseases with occupational relevance $[9,10]$. The NOSQ-2002 exists in a short and a long version. The original English version has already been translated into Danish, Finnish, Icelandic, Swedish, Spanish and Catalan [11], allowing the comparison of epidemiological data between studies and countries [9]. However, its use in Germany is limited due to the lack of a German version.

Thus, the aim of this study was to cross-culturally translate and adapt the two versions of the questionnaire with a particular emphasis on comprehensibility, clarity and appropriateness (e.g. time to complete, relevance).

\section{Materials and methods}

The NOSQ-2002 questionnaire

Within the NOSQ-2002 project of the Nordic Occupational Skin Questionnaire Group, a short and a long questionnaire (NOSQ-2002/SHORT and NOSQ-2002/LONG) were developed to be used in the general population. They have been compiled by using existing questionnaires and experience [9]. The NOSQ-2002/SHORT consists of 13 questions with four categories and can be used for the screening and monitoring of hand and forearm eczema (e.g. in a certain population group or at a certain workplace). All questions in the NOSQ-2002/SHORT are also included in the long version. The NOSQ-2002/LONG includes 57 questions grouped into 10 dimensions and is designed for occupational skin disease or hand eczema research. It is a pool of questions which can be chosen according to research needs and specified to particular population. An overview on the 10 dimensions (NOSQ2002/LONG) is shown in Table 1 [9,11].

Table 1 The 10 dimensions of the long version of the questionnaire (NOSQ-2002/LONG) and question items included in NOSQ-2002/SHORT $[9,11]$

\begin{tabular}{|c|c|c|c|}
\hline \multicolumn{2}{|l|}{ NOSQ-2002/LONG } & \multicolumn{2}{|c|}{ NOSQ-2002/SHORT } \\
\hline Question numbers & Question set & $\begin{array}{l}\text { Question } \\
\text { numbers }\end{array}$ & Items \\
\hline \multirow[t]{7}{*}{ General (G1 - G8) } & Demographics and occupational history & G1 & Workplace and Department \\
\hline & & $\mathrm{G} 2$ & Sex \\
\hline & & G3 & Year of birth \\
\hline & & G5 & Present occupation, from which year? \\
\hline & & G6 & Major activity at work since which year? \\
\hline & & G7 & Hours per week in main job (on average)? \\
\hline & & G8 & $\begin{array}{l}\text { Any other paid work regularly, type and hours per } \\
\text { week? }\end{array}$ \\
\hline Atopy (A1 - A4) & History of atopic symptoms & A1 & UK-working party single question on atopic eczema \\
\hline \multirow[t]{3}{*}{ Dermatitis (D1 - D12) } & Self-reported hand or forearm eczema & D1 & Have you ever had hand eczema? \\
\hline & & $\mathrm{D} 2^{*}$ & $\begin{array}{l}\text { Have you ever had eczema on your wrists or forearms } \\
\text { (excluding fronts of elbows)? }\end{array}$ \\
\hline & & D5* & $\begin{array}{l}\text { When did you last have eczema on your hands, wrists } \\
\text { or forearms? }\end{array}$ \\
\hline \multirow[t]{3}{*}{ Factors (F1 - F4) } & Exacerbating factors & $\mathrm{F} 1$ & Exacerbating factors in work \\
\hline & & $\mathrm{F} 2$ & Exacerbating factors outside work \\
\hline & & $\mathrm{F} 4$ & Improvement of eczema when away from normal work. \\
\hline Consequences (C1 - C3) & Consequences and life impact of dermatoses & & \\
\hline Urticaria (U1 - U9) & $\begin{array}{l}\text { Self-reported contact urticarial on hands or } \\
\text { forearms }\end{array}$ & & \\
\hline Symptoms (S1 - S5) & Skin symptoms & & \\
\hline Tests (T1 - T3) & Skin Tests & & \\
\hline Exposure (E1 - E8) & Exposures & & \\
\hline Health/Household (H1 - H2) & General Health and household size & & \\
\hline
\end{tabular}




\section{Translation and cross-cultural adaptation}

The goal of the cultural adaptation process is to reach a maximum accordance between the target version and the original English questionnaire. However, a linguistic translation of high quality is not sufficient. The challenge is to adapt the instrument in a culturally relevant and comprehensible manner, while retaining the content and meaning of the original questions [12]. In the literature, different translation approaches of instruments into other languages and cultures have been described [13-15].

The translation process of the NOSQ-2002 shown below was carried out according to the guidelines of the Principles of Good Practices of the International Society for Pharmacoeconomics and Outcomes Research (ISPOR) [15]. ISPOR formed the Translation and Cultural Adaption group (TCA group) which reviewed evidence from current practice as well as literature and existing guidelines. The report of the results of the review describes the principles with associated explanations and outlines the potential risks of non-observance [15].
After obtaining permission from the authors of the original version to translate the NOSQ-2002 into German, the translation process was carried out according to the steps outlined in Figure 1. The study was conducted within the years 2012 and the beginning of 2013.

I. Forward translation: The first step involved the translation of the original English version of the NOSQ-2002 into German by two independent bilingual native German speakers (SD, KR).

II. Reconciliation: The reconciliation was carried out by the project coordinator (MG). The two German versions were compared and adjusted to create a synthesis version of the translation. Where discrepancies occurred, an expert committee (JS, CA \& AS) consisting of two dermatology experts and one epidemiological expert came together to take a decision by consensus.

III. Back translation: This first target version (target version-1) was translated by two independent native

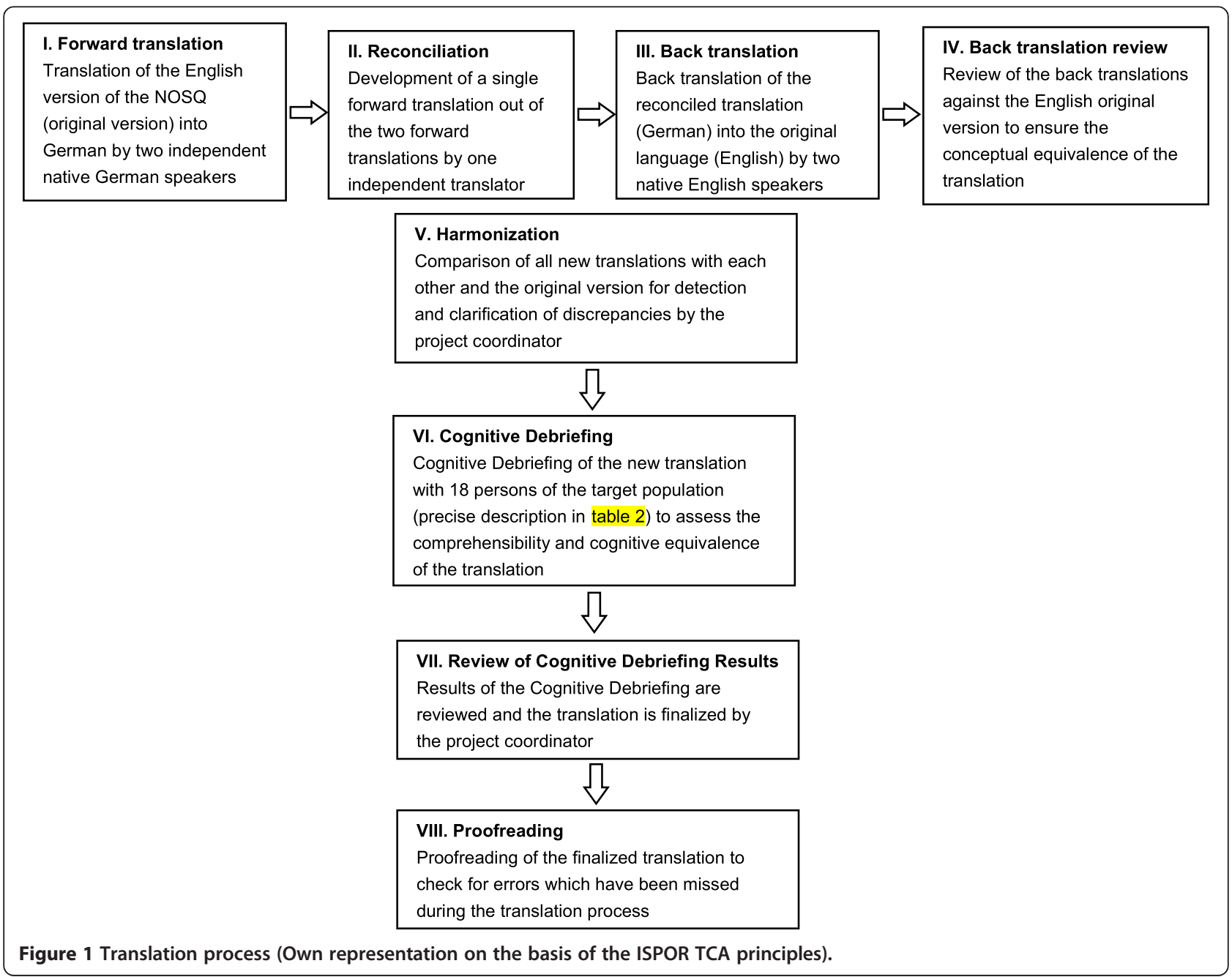


Table 2 Demographic and clinical characteristics of the German interview participants

\begin{tabular}{|c|c|c|c|c|}
\hline Patient number & Presence of skin disease & Age & Sex & Occupation \\
\hline 1 & No & 27 & Male & Physical therapist \\
\hline 2 & No & 19 & Female & Student \\
\hline 3 & No & 22 & Male & Cleaner \\
\hline 4 & No & 54 & Female & Secretary \\
\hline 5 & No & 48 & Female & Clerical assistant \\
\hline 6 & Yes & 58 & Female & Temporary worker \\
\hline 7 & Yes & 55 & Female & Librarian \\
\hline 8 & Yes & 28 & Male & Physical therapist \\
\hline 9 & No & 29 & Male & Physical therapist \\
\hline 10 & No & 24 & Female & Physical therapist \\
\hline 11 & No & 77 & Male & Pensioner \\
\hline 12 & No & 72 & Male & Pensioner \\
\hline 13 & No & 29 & Male & Baker \\
\hline 14 & No & 39 & Male & Kindergarten teacher \\
\hline 15 & Yes & 48 & Female & Kindergarten teacher \\
\hline 16 & No & 26 & Female & Kindergarten teacher \\
\hline 17 & No & 52 & Female & Kindergarten teacher \\
\hline 18 & Yes & 46 & Female & Teacher \\
\hline
\end{tabular}

English speakers (JH, JB) with fluency in German back into English. Both of the translators were living in Germany. However, one translator's mother tongue was British English, whereas the mother tongue of the other speaker was American English. One of the translators had experience in occupational medicine research while the other translator had no background knowledge, ensuring high quality-control of the translation.

IV. Back translation review: Both independent back translations were compared to the original version of the questionnaire by the project coordinator (MG) to ensure the conceptual equivalence of the translated version. If there were discrepancies detected by the project coordinator, the expert committee (already mentioned within step II. Reconciliation) again took a decision by consensus.

V. Harmonization: Within the fifth step all translations and the original version were compared with each other by the project coordinator (MG) to detect possible discrepancies. If discrepancies were detected, the expert committee (JS, CA \& AS) came together to take a decision by consensus. By clearing these discrepancies the conceptual equivalence and the high-quality of the translation were furthermore ensured. The harmonization resulted in a German version of the questionnaire (target version-2) that was ready to be tested.
VI. Cognitive Debriefing: In order to test the comprehensibility and acceptability of target version-2, cognitive interviews were performed $[12,16,17]$. The interviews were assisted by a trained interviewer (LS) who first explained the nature of the questionnaire as well as the aim of the study and obtained participants' informed consent. Both patients with dermatological complaints and healthy subjects were involved.

First all participants completed the long version of the translated questionnaire, which includes all of the questions asked in the shorter version, on their own. The participants had the opportunity to comment after each question and in relation to the questionnaire as a whole.

Table 3 Questions and answers of the self-developed questionnaire for the cognitive debriefing interviews

Were the instructions for filling out the questionnaire comprehensible to you?

Yes: 11 (61\%) Rather yes: 7 (39\%) Medium: 0 rather no: 0 No: 0

Did the filling out of the questionnaire demand too much time?

Yes: 3 (17\%) No: 15 (83\%)

Did you feel uncomfortable while filling out the questionnaire?

Yes: $0 \quad$ No: 18

Did you feel able to answer all the questions?

Yes: 13 (72\%) No: 5 (28\%) 


\section{Table 4 Modifications of items of the NOSQ-2002 during the translation and cross-cultural adaption process into}

\section{German}

Items in the original English version

Instructions and examples: 5. Do not pay attention to the numbers after the boxes. "No" is always $\square 1$ and "yes" is $\square 2$. The other boxes are numbered from 3 on

G4 Are you at the moment?(only one answer)

Employed

Self-employed

Full-time homemaker

Unemployed

Student

Apprentice/trainee

On maternity/paternity leave

Retired/pensioner

Other, what?

D1 Have you ever had hand eczema?

F4 Does your eczema improve when you are away from your normal work (for example weekends or longer periods? (One answer in each column if applicable)

No

\section{Modifications within the German version}

For the sake of completeness it was supplemented that "don't know" is always $\square 0$.

\section{German version:}

Achten Sie nicht auf die Zahlen nach den Kästchen. "Nein "ist immer $\square 1$ "ja" ist $\square 2$ und "weiss nicht"ist $\square$ 0. Die anderen Kästchen sind von 3 an nummeriert.

People did not know what to answer if they were "civil servants". A new category ("verbeamtet") was supplemented

\section{German version:}

G4 Sind Sie zurzeit .? (nur eine Antwort)

Angestellt

\section{Verbeamtet}

Selbstständig/privater Angestellter

Vollzeit Hausfrau/Hausmann

Erwerbslos

Student

Auszubildender/Praktikant

In Mutterschafts-Naterschaftszeit

Pensioniert/Rentner

Sonstiges, was?

Some people did not understand the difference between questions G5 and G6. A short explanation was supplemented to clarify that within G5 the "job title" is meant.

German version

G5 Was ist Ihr derzeitiger Beruf (Berufsbezeichnung)?

People need an example for what is meant with "itchy rash". Two examples were supplemented (e.g. eczema, atopic dermatitis etc.)

German version:

A1 Hatten Sie jemals für mindestens 6 Monate einen juckenden Hautausschlag wechselnder Ausprägung (z.B. Ekzem, Neurodermitis etc.), der irgendwann auch Hautfalten betroffen hat?

For classification people need a clarification of signs and symptoms of the disease. A short definition and the main symptoms of hand eczema were supplemented (non-contagious inflammation of the skin on the hands; symptoms: itching, erythema, blistering, cracks).

German version:

D1 Hatten Sie jemals ein Handekzem (nicht ansteckende Entzündung der Haut an den Händen; Symptome: Juckreiz, Hautrötung, Bläschenbildung, Krustenbildung)

People did not know what to answer if the eczema "always" improves when they are away from work. A new category "yes, always" was supplemented.

German version: 
Table 4 Modifications of items of the NOSQ-2002 during the translation and cross-cultural adaption process into German (Continued)

Yes, sometimes

Yes, usually

Don't know
F4 Verbessert sich Ihr Ekzem, wenn Sie Ihrer normalen Arbeit fernbleiben (zum Beispiel an den Wochenenden oder während längeren arbeitsfreien Zeiträumen)? (wenn zutreffend, eine Antwort in jeder spalte)

nein

ja, manchmal

ja, normalerweise

ja, immer

weiss nicht
They also had the chance to consult the interviewer if they had difficulty in understanding questionnaire content. All written and oral comments and questions were recorded and taken into account while reviewing the new translated instrument.

After completion of the questionnaire, the interviewer conducted a semi-standardised interview with each participant using four self-developed questions regarding the comprehensibility, acceptability and applicability of the translated instrument.

VII. Review of the cognitive debriefing: Within this seventh step the results of the cognitive debriefing were implemented in order to produce a first final version. All of the completed questionnaires, comments and replies were taken into account in order to detect potential misunderstandings, e.g. words that were not familiar to the participants, misleading instructions or ambiguities.

VIII. Proofreading: Lastly, the final version was proofread by the project coordinator to detect potential errors (e.g. orthography and grammar) that were missed within the translation process.

\section{Results}

\section{Cognitive debriefing}

The comprehensibility of the questionnaire was tested with a total of 18 persons (healthy and skin disease afflicted) with diverse socio-demographic characteristics. It was a very heterogeneous sample regarding sex, age and occupation (Table 2). By choosing this diverse group it can be ensured that the questionnaire is comprehensible for a wide range of people.

The questions utilised within the semi-standardised interview as well as the corresponding results are shown in Table 3.

The entire cognitive debriefing took about 30 minutes on average per person (completion of the NOSQ-2002/ LONG including interview). However, there was a sizeable variation in time needed, strongly depending on the individuals. Some persons rated the processing of the survey instrument as very time-consuming.

Overall, the questionnaire was well understood by all 18 participants. The questionnaire was considered relevant, appropriate and easy to understand. Only few questions were partly difficult to understand for the participants and required modifications. Mostly, more explanations were necessary for a better understanding, several technical terms were generalised or new answer categories were supplemented. All modifications made are shown in Table 4.

\section{NOSQ-2002: German version}

As a result of the translation process, a long and short German version of the NOSQ-2002 is now available at www.nrcwe.dk/NOSQ. Thereby, an instrument for the self-evaluation of skin diseases and work-related as well as non-work-related exposures is now available for German-speaking regions.

The short questionnaire includes questions that can be used for the screening and supervision of work-related skin diseases, i.e. in a particular population or workplace.

The long version contains further details about demographic factors, occupational career, history of atopic symptoms, self-reported hand- and forearm eczema as well as contact urticaria, skin symptoms, skin-tests, exposures and overall health. These details can be used for research comparing exposures and skin diseases in different countries or to assess the epidemiology of skin diseases in general.

\section{Discussion}

With the German translation of the NOSQ-2002 presented here, the long and short version of the questionnaire is now available in nine different languages (Danish; English; Finnish; Icelandic; Swedish; Catalan; Norwegian; Spanish and German). Following the seven steps of the cross-cultural adaptation guidelines outlined in the 
Principles of Good Practices by the ISPOR [15], the equivalence of the German questionnaires and the original English versions has been ensured. The translated questionnaires are comprehensible for German participants with respect to language as well as cultural context. To achieve this, only few modifications of the English version were necessary. In particular, the clarity and ease of processing of the questionnaire by the participants was given precedence.

Regarding future application, it can be already stated that the long version of the questionnaire was frequently considered to be very time-consuming by the participants. Therefore, in order to not affect response rate, it should be carefully considered which version of the questionnaire is appropriate for a particular purpose. As part of the introduction, it should also be made clear that not all participants need to answer all of the questions. For example, individuals without hand eczema do not need to answer questions specific to hand eczema and can move on to the next set of questions. It is likely that this will also lead to a greater willingness to participate. These two issues are not limited to the German questionnaire, but apply to the usage of the NOSQ-2002 in general.

Recently, squamous cell carcinoma of the skin caused by solar UV-exposure has been identified as a new occupational skin disease in Germany [18]. The NOSQ-2002 does not include appropriate questions about skin cancer, occupational UV-exposure or signs of damage of the skin through UV-exposure.

The translation and cross-cultural adaptation of the NOSQ-2002 is the first step to obtain a standardized instrument for collection of epidemiological data on work-related skin diseases in Germany. In order to meet scientific standards, the questionnaire's quality still must be investigated. To this end, the testing of the measurement properties (validity, reliability etc.) is essential and planned in future work (at least of the short version). The validity of the instrument will be tested within the fieldwork of the occupational health service of a German university medical centre. In this context, patients of this ward will be interviewed consecutively. The results of the survey will be compared with a medical examination of each patient (gold standard). The instrument's test-retest reliability will be tested by comparing the answers from the same respondents at two time points (interval of two weeks).

The NOSQ-2002 has already been used in many international studies on occupational skin diseases including, e.g. Denmark [19-23], Finland [24,25], the Netherlands [26] and the USA $[27,28]$. With the German version of the NOSQ-2002, the collection of standardized data on this important occupational disease will be possible in Germany as well. In addition, it will be possible to compare existing data between studies as well as countries. This will provide new opportunities for describing the epidemiology of occupational skin diseases and help evaluate prevention measures.

Furthermore, the differences in occupational skin diseases between different countries can be detected. Thus the impact of different exposure levels or different working methods on the risk of acquiring occupational skin diseases can be examined. This can indicate again new approaches for the decrease of harmful exposures to improve the prevention of work-related skin diseases [9].

\section{Conclusion}

A linguistically validated version of the NOSQ-2002 is now available for German speaking regions. This is a prerequisite for future assessments of occupational skin diseases in accordance with international standards. Further research is necessary to examine the psychometric properties of the German NOSQ-2002. After final adaptation, the German version of the NOSQ-2002 will enable the standardized assessment of skin diseases in occupational settings in Germany and German speaking countries.

\section{Competing interests}

The authors declare that they have no competing interests.

\section{Authors' contributions}

MG: drafting/revising of the manuscript, study concept and design, study coordination, reconciliation and harmonization of the different versions of the questionnaire within the translation process. LS: drafting/revising of the manuscript, realization of the cognitive debriefing. $\mathrm{JH}$ : revising of the manuscript, translation of the first target version back into English. CA: revising of the manuscript, member of the expert committee. AS: revising of the manuscript, member of the expert committee. SD: forward translation of the original version into German. KR: forward translation of the original version into German. JB: translation of the first target version back into English. M-AF: critical reviewing of the article and the translation process. JS: study concept and design, study supervision. All authors approved and critically reviewed the final version of the manuscript.

\section{Author details}

${ }^{1}$ TU Dresden, Faculty of Medicine, Institute and Policlinic of Occupational and Social Medicine, Dresden, Germany. ${ }^{2}$ University of Regensburg, Institute of Epidemiology and Preventive Medicine, Regensburg, Germany. ${ }^{3}$ The National Research Centre for the Working Environment, Lersø Parkallé 105, Copenhagen DK-2100, Denmark.

Received: 19 March 2014 Accepted: 11 August 2014

Published online: 10 September 2014

\section{References}

1. Diepgen TL: Occupational skin diseases. JDDG 2012, 10:297-315.

2. Lushniak BD: The importance of occupational skin diseases in the United States. Int Arch Occup Environ Health 2003, 76(5):325-330.

3. Ahn YS, Kim MG: Occupational skin diseases in Korea. J Korean Med Sci 2010, 25(Suppl):46-52.

4. Meding B, Lantto R, Lindahl G, Wrangsjö K, Bengtsson B: Occupational skin disease in Sweden - a 12-year follow-up. Contact Dermatitis 2005, 53(6):308-313.

5. Goon AT-J, Goh C-L: Epidemiology of occupational skin disease in Singapore 1989-1998. Contact Dermatitis 2013, 43(3):133-136.

6. BAuA (Bundesanstalt für Arbeitsschutz und Arbeitsmedizin): Sicherheit und Gesundheit bei der Arbeit 2012-Unfallverhütungsbericht Arbeit. Dortmund; 2014

7. Skudlik C, Breuer K, Jünger M, Allmers H, Brandenburg S, John SM: Optimierte Versorgung von Patienten mit berufsbedingten 
Handekzemen: Hautarztverfahren und Stufenverfahren Haut der gesetzlichen Unfallversicherung. Hautarzt 2008, 59:690-695.

8. Voss H, Gediga G, Gediga K, Mentzel F, Skudlik C, Zagrodnik F-D, John SM: Sekundärprävention von Berufsdermatosen: erste systematische Evaluation des Hautarztverfahrens und des Stufenverfahrens Haut. JDDG 2013, 11:662-672

9. Susitaival P, Flyvholm M-A, Meding B, Kanerva L, Lindberg M, Svensson A, Ólafsson JH: Nordic Occupational Skin Questionnaire (NOSQ-2002): a new tool for surveying occupational skin diseases and exposure. Contact Dermatitis 2003, 49:70-76.

10. Flyvholm M-A, Susitaival P, Meding B, Kanerva L, Lindberg M, Svensson A, Ólafsson JH: Nordic Occupational Skin Questionnaire - NOSQ-2002. Nordic Questionnaire for Surveying Work-related Skin Diseases on Hands and Forearms and Relevant Exposures. 518th edition. TemaNord Copanhagen: Nordic Council of Ministers; 2002:1-186.

11. Sala-Sastre N, Herdmann M, Navarro L, de la Prada M, Pujol RM, Serra C, Alonso J, Flyvholm M-A, Giménez-Arnau AM: Principles and methodology for translation and cross-cultural adaptation of the Nordic Occupational Skin Questionnaire (NOSQ-2002) to Spanish and Catalan. Contact Dermatitis 2009, 61:109-116.

12. Beaton DE, Bombardier C, Guillemin F, Ferraz MB: Guidelines for the process of cross-cultural adaptation of self-report measures. SPINE 2000, 25(24):3186-3191.

13. Sperber AD: Translation and validation of study instruments for cross-cultural research. Gastroenterology 2004, 126:124-128.

14. Maneesriwongul W, Dixon JK: Instrument translation process: a methods review. J Adv Nurs 2004, 48:175-186.

15. Wild D, Grove A, Martin M, Eremenco S, McElroy S, Verjee-Lorenz A, Erikson $P$ : Principles of good practice for the translation and cultural adaptation process for Patient-Reported Outcomes (PRO) measures: report of the ISPOR task force for translation and cultural adaptation. Value Health 2005, 8(2):94-104.

16. Bühner M: Einführung in die Test- und Fragebogenkonstruktion. München: Pearson Studium; 2006

17. Moosbrugger $\mathrm{H}$, Kelava A: Testtheorie und Fragebogenkonstruktion. Heidelberg: Springer Medizin Verlag; 2007.

18. Schmitt J, Seidler A, Diepgen B: Occupational ultraviolet light exposure increases the risk for the development of cutaneous squamous cell carcinoma: a systematic review and meta-analysis. Br J Dermatol 2011, 164(2):291-307.

19. Jepsen KF, Flyvholm M-A: Identification of subjects with atopic dermatitis in questionnaire studies. Contact Dermatitis 2007, 56(4):218-223.

20. Sell L, Flyvholm M-A, Lindhard G, Mygind K: Implementation of an occupational skin disease prevention programme in Danish cheese dairies. Contact Dermatitis 2005, 53(3):155-161.

21. Ibler KS, Agner T, Hansen JL, Gluud C: Study protocol: the Hand Eczema Trial (HET): design of a randomised clinical trial of the effect of classification and individual counselling versus no intervention among health-care workers with hand eczema. BMC Dermatol 2010, 10:8.

22. Flyvholm M-A, Mygind K, Sell L, Jensen A, Jepsen KF: A randomised controlled intervention study on prevention of work-related skin problems among gut cleaners in swine slaughterhouses. Occup Environ Med 2005, 61:642-649.

23. Flyvholm M-A, Bach B, Rose M, Jepsen KF: Self-reported hand eczema in a hospital population. Contact Dermatitis 2007, 57(110):115.

24. Suuronen K, Jolanki R, Luukkonen R, Alanko K, Susitaival P: Self-reported skin symptoms in metal workers. Contact Dermatitis 2007, 57(4):259-264.

25. Mälkönen T, Jolanki R, Alanko K, Luukkonen R, Aalto-Korte K, Lauerma A, Susitaival P: A 6-month follow-up study of 1048 patients diagnosed with an occupational skin disease. Contact Dermatitis 2009, 61(5):261-268.

26. van der Meer EWC, Boot CR, van der Gulden JW, Jungbauer FH, Coenraads PJ, Anema JR: Hand eczema among healthcare professionals in the Netherlands: prevalence, absenteeism, and presenteeism. Contact Dermatitis 2013, 69(3):164-171.
27. Roelofs C, Azaroff LS, Holcroft C, Nguyen H, Doan T: Results from a community-based occupational health survey of Vietnamese-American nail salon workers. J Immigr Minor Health 2008, 10(4):353-361.

28. Crawford GH, Katz KA, Ellis E, James WD: Use of aromatherapy products and increased risk of hand dermatitis in massage therapists. Arch Dermatol 2004, 140:991-996.

doi:10.1186/s12995-014-0029-2

Cite this article as: Girbig et al:: Translation and cross-cultural adaptation of the Nordic Occupational Skin Questionnaire (NOSQ-2002) to German. Journal of Occupational Medicine and Toxicology 2014 9:29.

\section{Submit your next manuscript to BioMed Central and take full advantage of:}

- Convenient online submission

- Thorough peer review

- No space constraints or color figure charges

- Immediate publication on acceptance

- Inclusion in PubMed, CAS, Scopus and Google Scholar

- Research which is freely available for redistribution

Submit your manuscript at www.biomedcentral.com/submit
( BioMed Central 